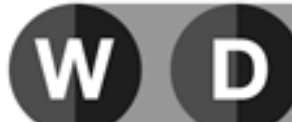

William Davidson Institute

AT THE UNIVERSITY OF MICHIGAN

\title{
The Distribution Dynamics of Income in Central and Eastern Europe relative to the EU: A Nonparametric Analysis
}

By: Nikolay Nenovsky and Kiril Tochkov

William Davidson Institute Working Paper Number 1063 November 2013 
The Distribution Dynamics of Income in Central and Eastern Europe relative to the EU:

A Nonparametric Analysis

\author{
Nikolay Nenovsky ${ }^{*}$ \\ Université de Picardie and ICER
}

Kiril Tochkov ${ }^{\dagger}$

Texas Christian University

\begin{abstract}
After more than two decades of transition and integration, countries in Central and Eastern Europe (CEE) still exhibit income levels that are significantly lower than the European Union (EU) average. This paper examines convergence in per-capita GDP between CEE and the EU over the period 1990-2012 by employing a combination of parametric and nonparametric methods, which provide more detailed insights than previous studies. The results indicate that the first decade of transition has been marked by divergence from the EU benchmark. In contrast, CEE countries experienced strong convergence over the 2000s, even in the face of the global financial crisis. However, the distribution of relative income evolved from a unimodal to a multimodal one, revealing growing disparities within CEE. Human capital accumulation and progress in economic reforms are identified as the key determinants of convergence, while financial deepening and price instability had a negative effect, especially in the past decade.
\end{abstract}

JEL Codes: O47; O57; C14

Keywords: income convergence; nonparametric methods; European Union; Central and Eastern Europe

\footnotetext{
* CRIISEA, Université de Picardie Jules Verne, UFR d'Economie et de Gestion, Pôle Universitaire Cathédrale, 10 Placette Lafleur BP 2716, 80027 Amiens Cedex 1U, France. Email: nenovsky@gmail.com. ${ }^{\dagger}$ Department of Economics, Texas Christian University, Box 298510, Fort Worth, TX 76129, USA. Email: k.tochkov@tcu.edu.
} 


\section{Introduction}

Almost a quarter of a century has passed since the start of the transition towards democracy and a market economy in Central and Eastern Europe (CEE). In the process of shedding the legacy of the planned economy in the early 1990s, countries in the region were facing similar problems due to the shared political and economic system shaped for decades by Communist ideology. Accordingly, they adopted similar economic reforms aimed at establishing functioning market economies and collectively suffered a severe decline in aggregate output during this period. However, disparities in their initial conditions and in the sequencing, speed, and depth of reform implementation produced vastly different results across CEE. While some countries, like the Czech Republic, have managed to almost completely overcome the burden of their Communist past, others, like Belarus, still exhibit many of the traits of a state-run economy.

By creating a democratic society and a market economy, CEE countries also hoped to restore and deepen their integration with the advanced economies in Western Europe via accession to the European Union (EU). In 2004, the first group of Central European and Baltic countries joined the organization, followed by Bulgaria and Romania in 2007, and Croatia in 2013. At the same time, four countries (Slovakia, Slovenia, Estonia, and Latvia) have taken their integration a step further by adopting the euro as their national currency when they became members of the European Monetary Union (EMU). Despite these milestones in their development, CEE countries have ranked as the poorest members of the EU. As shown in Fig. 1, even the best performing economies in Central Europe had a mean per-capita income that was about $60 \%$ of the EU average in 2012, while those of Bulgaria and Romania were even less than 40\%. The economic boom in CEE during the early and mid-2000s offered hope for a more rapid 
convergence, but the global economic crisis and the European debt crises in 2008-2010 resulted in a serious setback for some countries in the region.

Fig. 1: Per-capita income in CEE (\% of EU average), 1990-2012

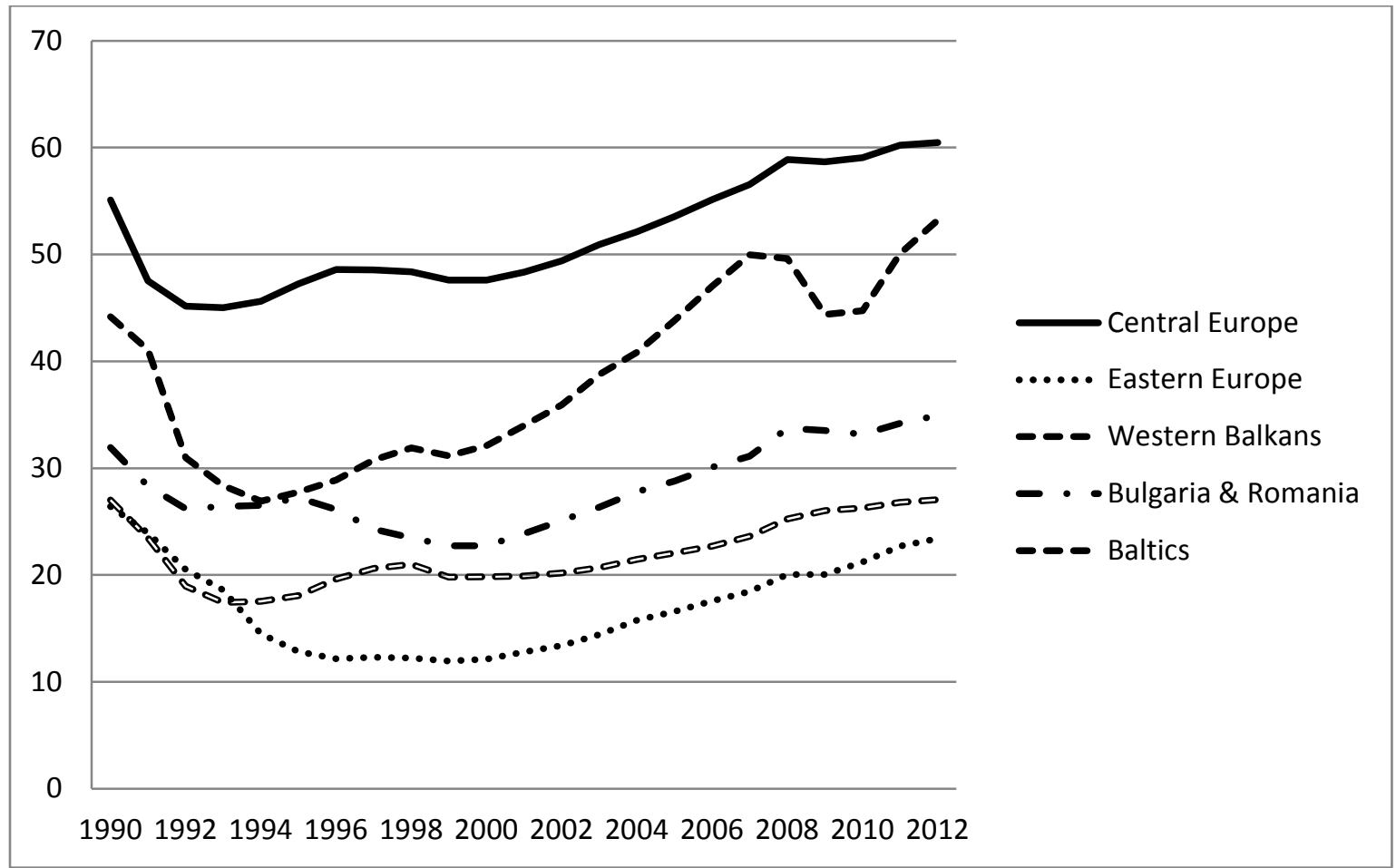

Note: Central Europe includes Croatia, Czech Republic, Hungary, Poland, Slovakia, and Slovenia. The Baltics include Estonia, Latvia, and Lithuania. Eastern Europe consists of Belarus, Moldovia, and Ukraine. The Western Balkans include Albania, Bosnia and Herzegovina, Macedonia, Montenegro, and Serbia.

The main goal of this paper is to examine the process of convergence between CEE and the EU over the entire period of transition. In particular, we use a combination of parametric and nonparametric methods to study the distributional dynamics of real per-capita GDP for 19 CEE countries relative to the EU average over the period 1990-2012. We construct kernel density distributions and analyze the evolution in their shape to trace convergence tendencies. Next, we employ Markov transition matrices and stochastic kernels to investigate the intradistributional 
dynamics and to estimate the probabilities of CEE countries' per-capita income convergence or divergence from the EU benchmark. Lastly, regression analysis enables us to identify the various factors that contributed to or impaired convergence over the sample period.

There is a vast literature on various aspects of convergence between CEE and the EU, including convergence in industrial output, prices, and interest rates (Brada, Kutan, and Zhou, 2005; Figuet and Nenovsky, 2006; Kasman, Kirbat-Kasman and Turgutlu, 2005; Kutan and Yigit, 2005), inflation (Becker and Hall, 2009; Drine and Rault, 2006; Nath and Tochkov, 2013), supply and demand shocks (Babetskii, Boone and Maurel, 2004; Fidrmuc and Korhonen, 2003), and fiscal (Ayala and Blazsek, 2012; Kocenda, Kutan, and Yigit, 2008) and monetary policy (Brada and Kutan, 2001). ${ }^{1}$ The papers dedicated to convergence in per-capita income can be divided into two groups. The first one employs growth regressions to estimate the presence of $\beta$ and $\sigma$-convergence. Matkowski and Prochniak (2007) provide evidence for both types of convergence between the EU and the eight CEE countries that joined the organization in 2004, whereby the catching up appears to have been more intense in the late 1990s and early 2000s as compared to earlier years. Vojinovic, Oplotnik, and Prochniak (2010) report very similar results for the same sample over the years 1996-2006. Szeles and Marinescu (2010) show that absolute convergence is significant only after adding Bulgaria and Romania to the sample, which also strengthens the conditional convergence of the entire CEE region. The work of Rapacki and Prochniak (2009) is the most comprehensive in terms of its sample of 27 transition economies and its time frame (1990-2005). ${ }^{2}$ The authors fail to find evidence of convergence for the entire sample and time period, but certain subsamples (e.g., the eight Central European countries) and

\footnotetext{
${ }^{1}$ Kocenda (2001) and Kutan and Yigit (2004) explore real and nominal convergence within the group of CEE countries, rather than between CEE and the EU.

${ }^{2}$ Their sample includes not only CEE but also all former Soviet republics, even those in the Caucasus and Central Asia.
} 
certain subperiods (e.g., 2000-2005) exhibit strong and significant $\beta$ - and $\sigma$-convergence tendencies.

The second group of papers seeks to detect stochastic convergence by applying variations of the unit root tests. For instance, Tsanana and Katrakilidis (2013) report limited income convergence among eight Balkan countries and between them and the EU average over the period 1994-2011. Similarly, Tsanana, Katrakilidis, and Pantelidis (2013) show that in Southeastern Europe only Slovenia and Greece exhibit convergence with the EU benchmark over the years 1989-2009.

The majority of previous studies have in common that they use parametric methodologies with a focus on the first two moments of the income distribution. The sign, magnitude, and significance of a single parameter are relied upon to determine the presence or lack of convergence. In contrast, the nonparametric approach applied in this paper explores the entire distribution of per-capita GDP and provides a much more detailed view of convergence dynamics within the CEE sample as well as between CEE and the EU. We also estimate directly the effects of the factors that drive or impair convergence, whereas the existing literature concentrates exclusively on the determinants of growth rather than convergence. Moreover, existing studies mostly limit their sample to EU members in CEE or other specific groups of countries, whereas we include all CEE countries, even though some of them are at the very early stages of accession talks and association agreements with the EU. An additional advantage of our analysis is that it examines the impact of the recent global economic crisis and European debt crisis on convergence between CEE and the EU.

The rest of the paper proceeds as follows. Sections 2 and 3 explain the methodology and data sources, respectively. Section 4 reports the results, and section 5 concludes. 


\section{Methodology}

In a series of seminal papers, Quah (1993, 1996a, b, 1997) criticized the standard econometric approaches to income convergence, arguing that their focus on the first $(\beta$ convergence) and second ( $\sigma$-convergence) moments of the income distribution describe the dynamics of a representative economy but fail to characterize the evolution of the entire income distribution over time. Instead, he proposed a new methodology that uses kernel density estimates to examine the shape of the income distribution and transition probability functions to investigate distributional dynamics and intra-distributional mobility. This approach is particularly suitable for the study of relative income convergence in CEE because of the heterogeneity across transition economies.

The nonparametric part of the analysis begins with the estimation of the probability density function of relative per-capita income using a kernel function. Let $X_{1}, \ldots, X_{n}$ be a sample of $n$ independent and identically distributed observations on a random variable $X$. The density value $f(x)$ at a given point $x$ is estimated by the following kernel density estimator:

$$
\hat{f}(x)=\frac{1}{n h} \sum_{i=1}^{n} K\left(\frac{x-X_{i}}{h}\right)
$$

where $h$ denotes the bandwidth of the interval around $x$ and $K$ is the kernel function. ${ }^{3}$ The kernel estimator assigns a weight to each observation in the interval around $x$, with the weight being inversely proportional to the distance between the observation and $x$. The density estimate consists of the vertical sum of frequencies at each observation. The resulting smooth curve allows us to visualize the shape of the distribution of relative per-capita income and detect the presence of “convergence clubs” represented by modes.

\footnotetext{
${ }^{3}$ We use data-driven bandwidth selection and a Gaussian kernel.
} 
Next, we study the dynamics of the relative income distribution and intradistributional mobility by estimating a transition probability matrix. Let $Q_{t}$ denote the distribution of relative per-capita across CEE countries at time $t$. The distribution at time $t+1$ is then described by:

$$
Q_{t+1}=M \times Q_{t}
$$

where $M$ is a finite discrete first-order Markov transition matrix that contains a complete description of the distributional dynamics as it maps $Q_{t}$ into $Q_{t+1}$. The transition matrix is given by

$$
M=\left(\begin{array}{ccc}
p_{i j} & \cdots & p_{i N} \\
\vdots & \ddots & \vdots \\
p_{N j} & \cdots & p_{N N}
\end{array}\right)
$$

where $p_{i j}$ with $i, j=1, . ., N$ is the probability of a transition from an initial state $i$ at time $t$ to a state $j$ at time $t+1$. The main diagonal of the matrix consists of the probabilities that an observation remains in the same state in $t$ and $t+1$.

Assuming that the transition probabilities from $t$ to $t+1$ are time-invariant and independent of any previous transitions, the evolution of intradistributional mobility can be studied by iterating Eq. (2) $k$ times. As $k \rightarrow \infty$, the iteration yields

$$
\lim _{k \rightarrow \infty} M_{j}^{k}=\delta_{j}>0, \quad \sum \delta_{j}=1
$$

The limiting probability distribution, $\delta_{j}$, is the unconditional or ergodic distribution. ${ }^{4}$ In other words, Eq.(4) describes the convergence to a steady-state distribution independent of the initial distribution. Accordingly, the ergodic distribution allows us to analyze the long-run tendencies of per-capita income in CEE countries relative to the EU benchmark, assuming that the observed dynamics continue to hold.

\footnotetext{
${ }^{4}$ The ergodic distribution is unique if there is only one eigenvalue of $M$ with modulus one.
} 
The transition probability matrix approach has two major drawbacks that might distort the distributional dynamics. First, it uses continuous data on relative per-capita income to estimate a discrete model. Second, the discretization of the state space into states $i$ and $j$, with $i, j=1, \ldots, N$ is somewhat arbitrary. To avoid these potential issues and test for the robustness of the results, we focus - in the third step of our analysis - on transition probabilities in a continuous state space and, following Quah (1997), estimate a stochastic kernel that maps the distribution $Q_{t}$ into $Q_{t+\tau}$ as follows:

$$
Q_{t+\tau}\left(x_{t+\tau}\right)=\int g\left(x_{t+\tau} \mid x_{t}\right) Q_{t}\left(x_{t}\right) d x
$$

where the conditional density function $g\left(x_{t^{+\tau} \tau} \mid x_{t}\right)$ describes the probability of the transition to a certain state in $t+\tau$ given the initial state in $t$. In line with Hyndman et al. (1996), the conditional density is estimated using a kernel estimator given by

$$
\hat{g}\left(x_{t+\tau} \mid x_{t}\right)=\frac{\hat{z}\left(x_{t+\tau}, x_{t}\right)}{\hat{f}\left(x_{t}\right)}
$$

where $f\left(x_{t}\right)$ is the marginal density from Eq. (1) and $z\left(x_{t+\tau}, x_{t}\right)$ is the joint density given by

$$
\hat{z}\left(x_{t+\tau}, x_{t}\right)=\frac{1}{n h b} \sum_{i=1}^{n} K\left(\frac{x_{t+\tau}-X_{i, t+\tau}}{b}\right)\left(\frac{x_{t}-X_{i t}}{h}\right)
$$

with $h$ and $b$ denoting the bandwidth of the interval around $x_{t}$ and $x_{t^{+} \tau}$ respectively. The visual representation of the stochastic kernel produces three-dimensional graphs and two-dimensional contour plots. Like a Markov transition matrix, the main diagonal in these graphs indicates a lack of mobility across states.

Lastly, we seek to identify the determinants of relative per-capita income growth via regression analysis. For this purpose, we estimate the following model:

$$
\begin{aligned}
& \Delta \ln \left(\frac{y_{i t}^{C E E}}{\bar{y}_{t}^{E U}}\right)=\propto_{i}+\beta_{1} K_{i t}+\beta_{2} H K_{i t}+\beta_{3} R \& D_{i t}+\beta_{5} O P E N_{i t}+\beta_{6} F D I_{i t}+\beta_{7} G O V_{i t}+ \\
& \beta_{8} M O N_{i t}+\beta_{9} F I N_{i t}+\beta_{10} F X_{i t}+\beta_{11} R E F_{i t}+\beta_{13} E U_{i t}+\beta_{14} C R I S_{i t}+\varepsilon_{i t}
\end{aligned}
$$


The dependent variable is the annual growth in real per-capita GDP of CEE country $i$ $(i=1, \ldots, 19)$ in year $t$ as a percentage of the EU average. ${ }^{5}$ For robustness purposes and to control for short-run fluctuations, we also estimate the model for average annual growth over 3-year non-overlapping periods as the dependent variable. The regression employs country-fixed effects $\left(\alpha_{i}\right)$ to control for the effects of unobserved confounding variables that vary across countries. All independent variables enter the equation at their initial level at the beginning of the period to minimize endogeneity issues.

The choice of regressors is largely guided by the standard growth literature (Barro, 1991; Levine and Renelt, 1992; Sala-i-Martin, Doppelhofer, and Miller, 2004), although our dependent variable measures convergence towards the EU benchmark over time. Physical $(K)$ and human capital $(H K)$ accumulation increase labor productivity and promote economic growth, which can lead to convergence if the growth rate in CEE is higher than the EU average. For similar reasons, we include innovation $(R \& D)$. External forces are represented by openness $(O P E N)$ and foreign direct investment (FDI). Economic policy is accounted for by fiscal (GOV) and monetary (MON) variables, while financial deepening $(F I N)$ and the exchange rate regime $(F X)$ focus on the role of financial factors. Institutions are represented by the progress of economic reforms (REF). Furthermore, we include dummy variables for the years in which a CEE country was a member of the EU (EU) and for the years of the global and debt crises (CRIS).

\section{Data}

The sample covers 19 countries in CEE over the period 1990-2012. Per-capita GDP is measured according to purchasing power parity in constant 2005 international dollars. Physical

\footnotetext{
${ }^{5}$ The EU average is calculated using data from all EU member countries except for those from CEE, Cyprus, and Malta. Moreover, for the sake of consistency, the average includes the same countries for all years of the sample period, although some of them had not yet joined the EU in the early 1990s.
} 
capital accumulation is measured as gross fixed capital formation. Innovation is represented by the expenditure on research and development (R\&D), while fiscal policy is approximated by government consumption spending. Openness is calculated as the sum of exports and imports. FDI is expressed as net inflows. Financial deepening is proxied by domestic credit to the private sector. All of the above variables are expressed as percentage of GDP. Monetary factors are approximated by price instability measured as the annual rate of CPI inflation. The aforementioned variables were collected from the World Bank’s World Development Indicators database. Human capital is represented by average years of total schooling for individuals aged 15 years and above, which are obtained from Barro and Lee (2013). ${ }^{6}$ The effects of the exchange rate regime are controlled for by a dummy variable that takes the value of 1 if the country adopted a fixed exchange rate, and 0 otherwise. Membership in the EU is also a dummy variable that takes the value of 1 if a CEE country joined the organization, and 0 otherwise. We adopt the European Bank of Reconstruction and Development (EBRD) transition indicator to measure the progress of economic reforms. This indicator consists of five components (large-scale privatization, small-scale privatization, governance and enterprise restructuring, price liberalization, trade and exchange rate liberalization, and competition policy), with progress measured on a scale ranging from 1 to 4 . We combine all components into an average composite score by assigning equal weights to each of them. ${ }^{7}$

The descriptive statistics for all variables in the regression analysis are shown in Table 1. The average per-capita income in CEE was 34\% of the EU average. All variables, except for government consumption and inflation, increased between the first and second decades of the sample period. Annual growth was negative over the years 1990-2000 when most CEE countries

\footnotetext{
${ }^{6}$ The average years of schooling are reported in 5-year intervals. We use interpolation to fill in the missing data for the years in between.

${ }^{7}$ The Czech Republic "graduated” from EBRD operations in 2007 and thus no data are available for later years.
} 
experienced a steep decline in output, but their performance turned positive in the following decade.

Table 1: Descriptive statistics

\begin{tabular}{|c|c|c|c|}
\hline & $\begin{array}{l}1990- \\
2012\end{array}$ & $\begin{array}{l}1990- \\
2000\end{array}$ & $\begin{array}{l}2001- \\
2012\end{array}$ \\
\hline $\begin{array}{l}\text { Real per-capita GDP } \\
\text { (\% of EU average) }\end{array}$ & $\begin{array}{c}33.88 \\
(16.50)\end{array}$ & $\begin{array}{c}30.83 \\
(15.26)\end{array}$ & $\begin{array}{c}36.67 \\
(17.12)\end{array}$ \\
\hline $\begin{array}{l}\text { Annual growth of } \\
\text { relative p.c. GDP }\end{array}$ & $\begin{array}{c}0.82 \\
(8.53)\end{array}$ & $\begin{array}{c}-1.74 \\
(10.89)\end{array}$ & $\begin{array}{c}3.38 \\
(3.76)\end{array}$ \\
\hline $\begin{array}{l}\text { Fixed capital formation } \\
\text { (\% of GDP) }\end{array}$ & $\begin{array}{l}22.30 \\
(5.50)\end{array}$ & $\begin{array}{l}20.94 \\
(5.77)\end{array}$ & $\begin{array}{l}23.41 \\
(5.01)\end{array}$ \\
\hline $\begin{array}{l}\text { Human capital } \\
\text { (avg. years of } \\
\text { schooling) }\end{array}$ & $\begin{array}{l}10.56 \\
(1.64)\end{array}$ & $\begin{array}{l}10.03 \\
(1.52)\end{array}$ & $\begin{array}{l}11.05 \\
(1.58)\end{array}$ \\
\hline $\begin{array}{l}\text { Openness } \\
\text { (trade as \% of GDP) }\end{array}$ & $\begin{array}{l}104.55 \\
(32.48)\end{array}$ & $\begin{array}{c}92.66 \\
(32.40)\end{array}$ & $\begin{array}{l}114.16 \\
(29.26)\end{array}$ \\
\hline $\begin{array}{l}\text { FDI } \\
\text { (\% of GDP) }\end{array}$ & $\begin{array}{c}4.69 \\
(5.74)\end{array}$ & $\begin{array}{c}2.76 \\
(2.53)\end{array}$ & $\begin{array}{c}6.04 \\
(6.87)\end{array}$ \\
\hline $\begin{array}{l}\text { Fiscal policy (gov. } \\
\text { consum. as \% of GDP) }\end{array}$ & $\begin{array}{c}9.66 \\
(3.31)\end{array}$ & $\begin{array}{l}10.43 \\
(3.45)\end{array}$ & $\begin{array}{c}8.87 \\
(2.97)\end{array}$ \\
\hline $\begin{array}{l}\text { Monetary policy } \\
\text { (CPI inflation in \%) }\end{array}$ & $\begin{array}{c}60.75 \\
(307.55)\end{array}$ & $\begin{array}{c}141.34 \\
(475.46)\end{array}$ & $\begin{array}{c}6.90 \\
(10.20)\end{array}$ \\
\hline $\begin{array}{l}\text { Financial deepening } \\
\text { (priv. lending as \% of } \\
\text { GDP) }\end{array}$ & $\begin{array}{c}37.60 \\
(23.25)\end{array}$ & $\begin{array}{c}25.64 \\
(18.85)\end{array}$ & $\begin{array}{c}45.21 \\
(22.60)\end{array}$ \\
\hline $\begin{array}{l}\text { Economic reforms } \\
\text { (EBRD transition score) }\end{array}$ & $\begin{array}{c}2.99 \\
(0.82)\end{array}$ & $\begin{array}{c}2.53 \\
(0.84)\end{array}$ & $\begin{array}{c}3.41 \\
(0.53)\end{array}$ \\
\hline $\begin{array}{l}\text { Innovation } \\
\text { (R\&D as \% of GDP) }\end{array}$ & $\begin{array}{c}0.75 \\
(0.39) \\
\end{array}$ & $\begin{array}{c}0.75 \\
(0.28) \\
\end{array}$ & $\begin{array}{c}0.75 \\
(0.43) \\
\end{array}$ \\
\hline Nr. of observations & 437 & 209 & 228 \\
\hline
\end{tabular}

Note: The reported numbers are averages across all countries and years. Standard deviations are in parenthesis. 


\section{Results}

\subsection{Distribution dynamics}

The density distributions of relative per-capita GDP are presented in Fig. 2. The threedimensional graphs on the left show the changes in the shape of the distribution over the entire sample period, while the two-dimensional plots provide snapshots for specific years. The graphs in the first and second row of Fig. 2 focus on the 1990s and 2000s, respectively.

At the start of the transition in 1990, the density distribution was unimodal, with most of the probability mass concentrated in the range between $30 \%$ and $60 \%$ of the EU average. Over the following five years, there is a clear shift of the distribution to the left, signifying divergence from the benchmark. In addition, a decrease in the dispersion of relative per-capita GDP produces a peak at around $20 \%-30 \%$ of the EU average, while a minor mode emerges at the $60 \%$

level. By the end of the first decade, there are some indications of convergence as the probability mass expands to the right, thereby reducing the height of the peak and absorbing the smaller mode.

The observed divergence over the 1990s coincides with the most difficult period of the transition in CEE, when many economies in the region experienced severe crises and initiated painful reforms that resulted in a dramatic fall in aggregate output. The weak convergence tendency of the late 1990s reflects the eventual success of these reforms in generating growth that allowed CEE countries to recover and begin catching up with the EU, albeit at a slow pace.

The distributional dynamics in the 2000s present a very different picture. There is a continuous shift of the distribution to the right, marking the convergence between CEE and the EU benchmark. At the same time, the widening of the main mode reveals a growing dispersion 
Fig. 2: Kernel density distributions of relative GDP per capita (\% of EU average), 1990-2012
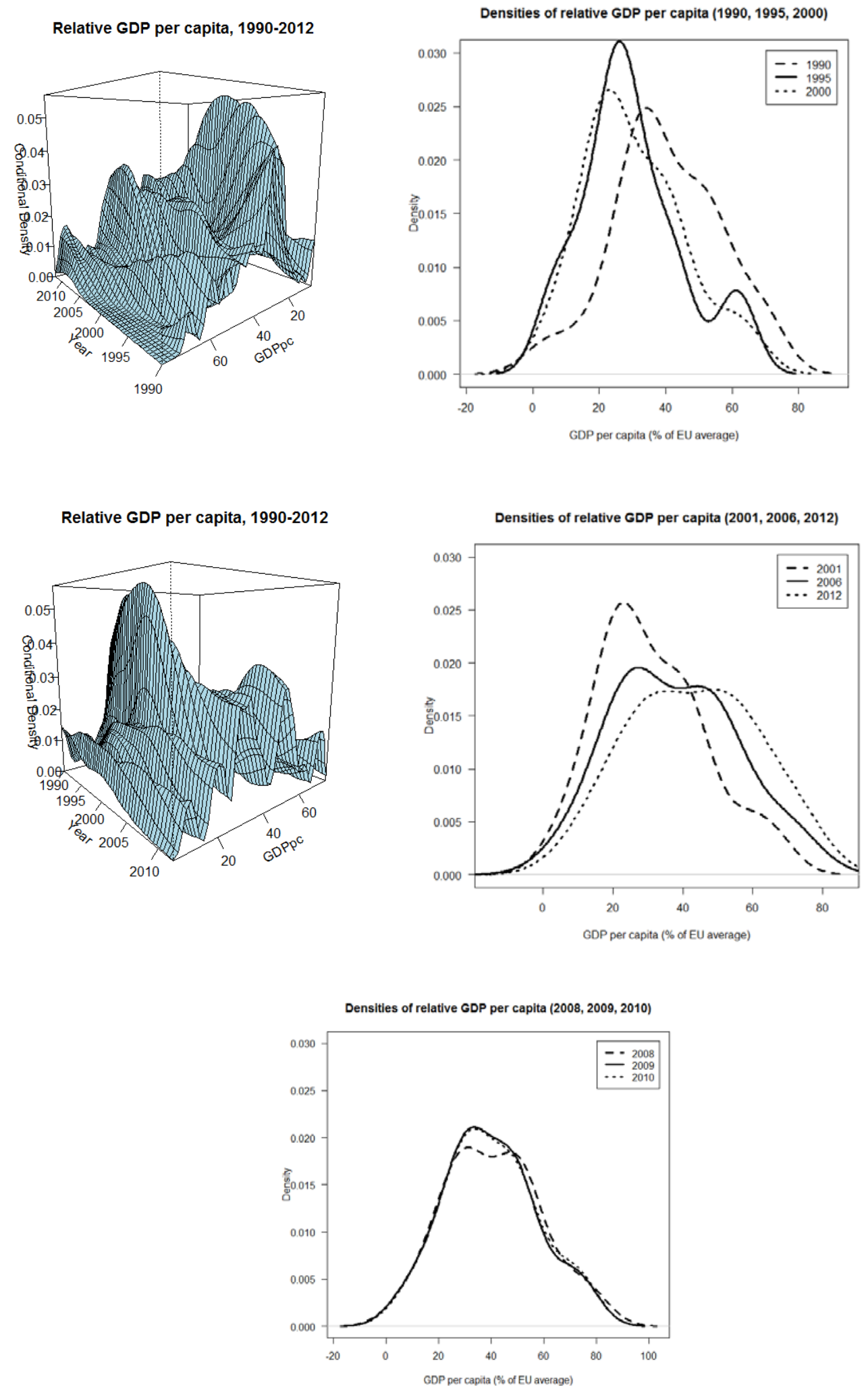
that results in the transformation of the unimodal into a multimodal distribution. The relatively high degree of smoothing in the two-dimensional plot conceals this tendency, but it can be observed on the corresponding three-dimensional graph. The single peak gradually dissipates and is replaced by a myriad of lesser modes. Although most of the probability mass has moved to the range between $40 \%$ and $70 \%$ of the EU average, a number of countries have remained at levels of between $10 \%$ and $30 \%$. These include mostly countries in the Western Balkans, such as Bosnia and Macedonia, as well as former Soviet republics, such as Ukraine and Moldova. Although they experienced an increase in relative per-capita GDP, the speed of convergence was moderate in comparison, confining them to the bottom of the distribution. For instance, Macedonia recorded a 27\% rise in its relative standing over the period 2001-2012, far behind Lithuania’s 72\% or Bulgaria’s 51\%. On the other end of the spectrum, countries like Slovenia and the Czech Republic achieved per-capita income levels of more than $70 \%$ of the EU average in recent years, thereby surpassing established EU members, such as Greece and Portugal, which were adversely affected by the debt crisis.

Interestingly, the global economic crisis and the European debt crisis have largely failed to slow down the overall convergence of CEE. The graph at the bottom of Fig. 2 shows only a very minor shift of the distribution to the left in 2009 and 2010. On the one hand, the crises devastated the economies of several EU countries causing the EU average to decrease and thus making it easier for CEE countries to catch up. On the other hand, some CEE countries, such as Poland, avoided a downturn and remained resilient throughout the crisis, while others like Romania and Latvia received generous financial assistance from the IMF and the EU, which prevented a major decline in their relative standing. 


\subsection{Intradistributional dynamics}

The transition matrices in Table 2 reveal the dynamics within the distribution of relative percapita GDP. Each matrix consists of four states, with ranges chosen so as to contain approximately the same number of observations. The initial states are displayed on the left, while the final states are in the top bar. The numbers in the matrix represent probabilities associated with moving from an initial to a final state. The diagonal embodies the persistence in the same state. Numbers below the diagonal indicate the likelihood of divergence, whereas the ones above measure the probability of convergence.

The first matrix in Table 2 uses annual transitions over the entire sample period. The persistence in the same initial state is above $90 \%$ and is identical at both ends of the distribution. In other words, countries with per-capita GDP of less than $23 \%$ and more than $45 \%$ of the EU average had little chance of changing their relative standing in the course of a year. In the middle of the distribution, the mobility is higher, but the chance of moving towards or diverging from the EU benchmark is almost the same. If sustained in the long run, these dynamics would have produced a bimodal ergodic distribution shown at the bottom of the matrix. Twenty-four percent of the observations would have ended up in the bottom mode, while 33\% would have concentrated at levels above $45 \%$ of the EU average.

We test the robustness of our results by extending the transition period to 3 years. This causes the mobility across states to increase dramatically, except at the top of the distribution, where it remains constant at above $90 \%$. Countries with relative per-capita income below $45 \%$ have a $17 \%$ to $20 \%$ chance of converging towards the EU benchmark, while the probability of divergence is between $11 \%$ and $15 \%$. In the long run, these convergence tendencies yield a unimodal ergodic distribution with a peak at the top and a long tail on the left. In general, this 
Table 2: Markov transition matrices and ergodic distributions

\begin{tabular}{|c|c|c|c|c|c|}
\hline \multicolumn{6}{|c|}{ Annual transitions, 1990-2012 } \\
\hline State & {$[4.1 ; 22.6)$} & {$[22.6 ; 30.5)$} & {$[30.5 ; 44.6)$} & {$[44.6 ; 77.8]$} & $\mathrm{n}$ \\
\hline$[4.1 ; 22.6)$ & 0.93 & 0.07 & 0.00 & 0.00 & 104 \\
\hline$[22.6 ; 30.5)$ & 0.06 & 0.87 & 0.08 & 0.00 & 105 \\
\hline$[30.5 ; 44.6)$ & 0.01 & 0.09 & 0.82 & 0.09 & 104 \\
\hline$[44.6 ; 77.8]$ & 0.00 & 0.00 & 0.07 & 0.93 & 105 \\
\hline Ergodic & 0.24 & 0.20 & 0.23 & 0.33 & 418 \\
\hline \multicolumn{6}{|c|}{ 3-year transitions, 1990-2012 } \\
\hline State & {$[4.1 ; 22.1)$} & {$[22.1 ; 29.5)$} & {$[29.5 ; 44.3)$} & {$[44.3 ; 77.8]$} & $\mathrm{n}$ \\
\hline$[4.1 ; 22.1)$ & 0.83 & 0.17 & 0.00 & 0.00 & 95 \\
\hline$[22.1 ; 29.5)$ & 0.11 & 0.69 & 0.20 & 0.00 & 95 \\
\hline$[29.5 ; 44.3)$ & 0.03 & 0.12 & 0.65 & 0.20 & 95 \\
\hline$[44.3 ; 77.8]$ & 0.01 & 0.01 & 0.06 & 0.92 & 95 \\
\hline Ergodic & 0.18 & 0.18 & 0.18 & 0.46 & 380 \\
\hline & \multicolumn{4}{|c|}{ Annual transitions, 1990-2000 } & \\
\hline State & {$[4.1 ; 21.7)$} & {$[21.7 ; 28.2)$} & {$[28.2 ; 41.0)$} & {$[41.0 ; 68.3]$} & $\mathrm{n}$ \\
\hline$[4.1 ; 21.7)$ & 0.96 & 0.04 & 0.00 & 0.00 & 47 \\
\hline$[21.7 ; 28.2)$ & 0.06 & 0.89 & 0.04 & 0.00 & 47 \\
\hline$[28.2 ; 41.0)$ & 0.04 & 0.15 & 0.77 & 0.04 & 48 \\
\hline$[41.0 ; 68.3]$ & 0.00 & 0.00 & 0.13 & 0.87 & 48 \\
\hline \multirow[t]{2}{*}{ Ergodic } & 0.58 & 0.32 & 0.08 & 0.03 & 190 \\
\hline & \multicolumn{4}{|c|}{ Annual transitions, 2001-2012 } & \\
\hline State & {$[4.1 ; 23.1)$} & {$[23.1 ; 32.9)$} & {$[32.9 ; 48.3)$} & {$[48.3 ; 77.8]$} & $\mathrm{n}$ \\
\hline$[4.1 ; 23.1)$ & 0.90 & 0.08 & 0.02 & 0.00 & 52 \\
\hline$[23.1 ; 32.9)$ & 0.00 & 0.89 & 0.11 & 0.00 & 53 \\
\hline$[32.9 ; 48.3)$ & 0.00 & 0.02 & 0.83 & 0.15 & 52 \\
\hline [48.3; 77.8] & 0.00 & 0.00 & 0.06 & 0.94 & 52 \\
\hline Ergodic & 0.00 & 0.05 & 0.27 & 0.68 & 209 \\
\hline
\end{tabular}


mirrors the ergodic distribution of the annual transitions matrix except that the lesser mode at the bottom has dissipated due to the higher mobility directed towards the top.

The matrices for the two subperiods again exhibit opposite patterns. Over the 1990-2000 period, the likelihood of divergence from the EU average was higher than of convergence. In the long run, this causes almost $60 \%$ of observations to end up with relative per-capita income of below $22 \%$. Accordingly, the ergodic distribution is unimodal and skewed to the right. In the years 2001-2012, the probability of divergence is only between $2 \%$ and $6 \%$ allowing the majority of countries to improve their relative standing. This convergence produces again a unimodal ergodic distribution, which is now skewed to the left. In the long run, almost $70 \%$ of observations would achieve a per-capita GDP of at least $48 \%$ of the EU average, while only $5 \%$ would have a relative level of less than $33 \%$.

We conduct an additional robustness check by estimating stochastic kernels that relax the assumption of a state space that consist of only 4 ranges. We use 3-year transitions and display the results in Fig. 3. The three-dimensional graphs and the corresponding two-dimensional contour plots are based on the same principle as the transition matrices, with the diagonal signifying persistence while a concentration of lines above (below) the diagonal is interpreted as convergence (divergence). The horizontal axis of the contour plots denotes the initial state of relative income at time $t$, and the vertical axis shows the corresponding level 3 years later $(t+3)$.

The results are mostly in line with the findings above. The wider dispersion of the lines on both sides of the diagonal for the first decade of the sample period reveals higher levels of mobility, which corresponds to the alternating divergence and convergence tendencies observed in Fig. 2. In contrast, the contour plots for the entire sample period and the second subperiod show much less dispersion, but the higher concentration of lines above the diagonal is indicative 
Fig. 3: Stochastic kernels of relative GDP per capita, 3-year transitions, 1990-2012
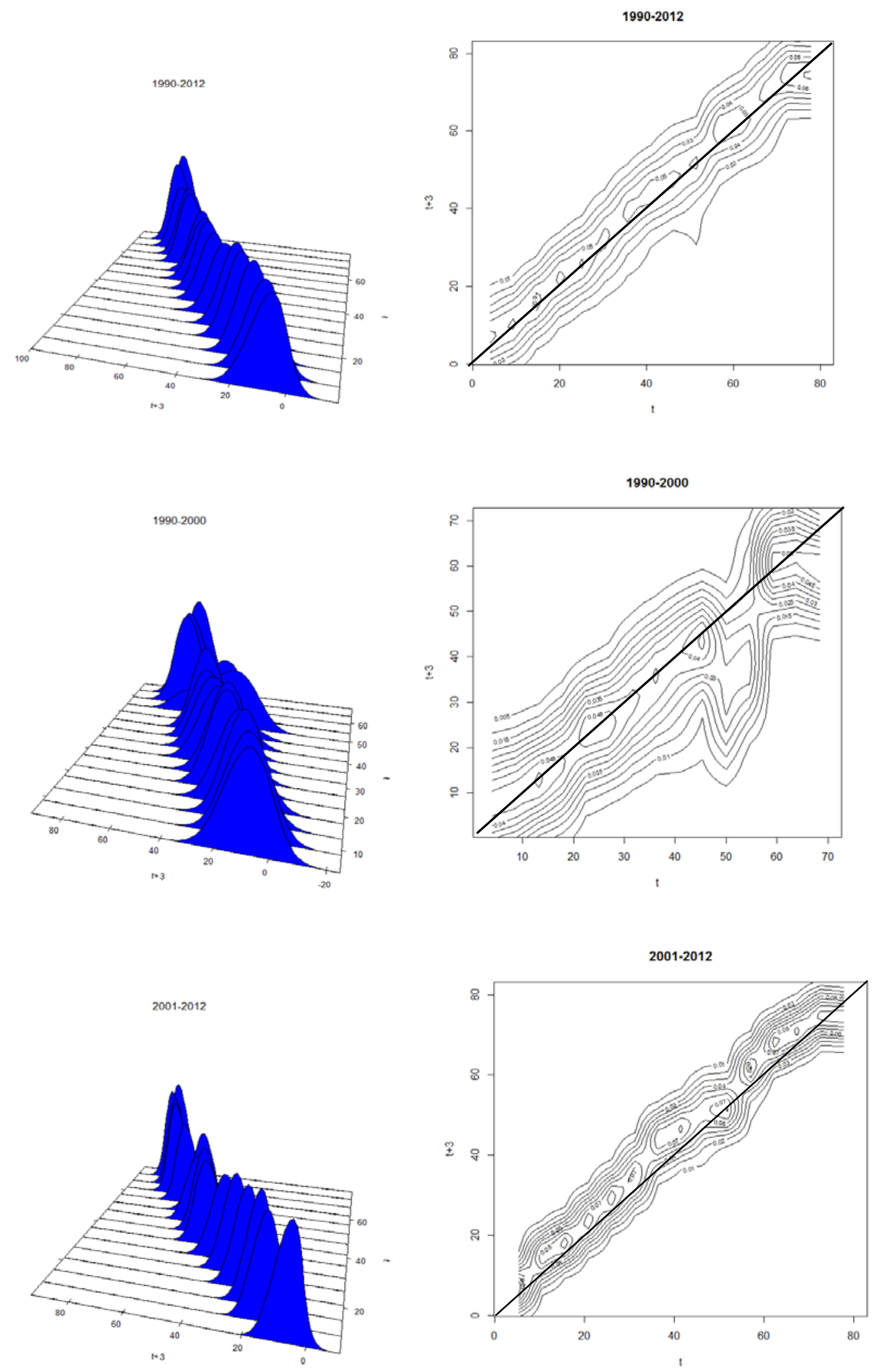
of convergence. This finding again concurs with the conclusions from the transition matrix analysis. In addition, the stochastic kernels provide more details that remain concealed by the discrete state space of the transition matrices. For instance, in the first decade of the sample period countries that initially had a relative per-capita GDP of around 50\% recorded a significantly higher chance of moving towards lower income levels in the following 3 years than their counterparts at both ends of the distribution.

\subsection{Determinants of relative per-capita income growth}

The factors that drive the distributional and intradistributional dynamics described in the previous two sections are explored via regression analysis. The results for several specifications of the fixed-effects model over the entire sample period are shown in Table 3, with the first two columns focusing on annual growth and the last two using average annual growth over 3-year non-overlapping periods. We should note again that the dependent variable is the growth of real per-capita GDP of CEE countries not in absolute terms but relative to the EU average. In other words, the dependent variable measures income convergence (or divergence) between CEE and the EU over time.

The estimates in Table 3 suggest that human capital is one of the key driving forces behind convergence. In the growth literature, human capital accumulation is one of the few factors that have been found to have a positive and robust effect on growth (Sala-I-Martin, Doppelhofer, and Miller, 2004; Henderson and Russell, 2005). In the case of CEE countries, we establish that average years of schooling not only promote subsequent economic growth but also convergence towards the EU average per-capita income. In other words, human capital enabled CEE to grow 
Table 3: Regression results for relative per-capita GDP growth, 1990-2012

\begin{tabular}{|c|c|c|c|c|}
\hline & \multicolumn{2}{|c|}{ Annual growth } & \multicolumn{2}{|c|}{ 3-year average growth } \\
\hline & (1) & $(2)$ & $(1)$ & $(2)$ \\
\hline Fixed capital formation & $\begin{array}{c}-0.194^{* *} \\
(0.081)\end{array}$ & $\begin{array}{c}-0.192 * * \\
(0.048)\end{array}$ & $\begin{array}{c}-0.467^{* * *} \\
(0.100)\end{array}$ & $\begin{array}{c}-0.478 * * * \\
(0.103)\end{array}$ \\
\hline Human capital & $\begin{array}{c}5.596 * * * \\
(1.593)\end{array}$ & $\begin{array}{c}3.351^{* *} \\
(1.356)\end{array}$ & $\begin{array}{c}3.648 \\
(2.699)\end{array}$ & $\begin{array}{c}0.500 \\
(2.507)\end{array}$ \\
\hline Openness & $\begin{array}{c}0.014 \\
(0.026)\end{array}$ & & $\begin{array}{c}0.007 \\
(0.039)\end{array}$ & \\
\hline FDI & $\begin{array}{c}0.029 \\
(0.051)\end{array}$ & $\begin{array}{c}0.039 \\
(0.050)\end{array}$ & $\begin{array}{c}0.048 \\
(0.079)\end{array}$ & $\begin{array}{c}0.035 \\
(0.085)\end{array}$ \\
\hline Fiscal policy & $\begin{array}{c}0.024 \\
(0.171)\end{array}$ & $\begin{array}{c}0.201 \\
(0.152)\end{array}$ & $\begin{array}{l}-0.055 \\
(0.567)\end{array}$ & $\begin{array}{c}0.681 \\
(0.537)\end{array}$ \\
\hline Price instability & $\begin{array}{l}-0.004 \\
(0.004)\end{array}$ & $\begin{array}{l}-0.003 \\
(0.004)\end{array}$ & $\begin{array}{c}-0.088^{* *} \\
(0.042)\end{array}$ & $\begin{array}{c}-0.141^{* * *} \\
(0.041)\end{array}$ \\
\hline Financial deepening & $\begin{array}{c}-0.088^{* * *} \\
(0.028)\end{array}$ & & $\begin{array}{c}-0.099 * * \\
(0.044)\end{array}$ & \\
\hline Fixed exchange rate & $\begin{array}{c}1.031 \\
(1.637)\end{array}$ & $\begin{array}{c}1.184 \\
(1.407)\end{array}$ & $\begin{array}{c}2.021 \\
(2.108)\end{array}$ & $\begin{array}{l}-1.415 \\
(1.926)\end{array}$ \\
\hline Economic reforms & $\begin{array}{c}5.316^{* * * *} \\
(1.622)\end{array}$ & $\begin{array}{c}5.277 * * * \\
(1.628)\end{array}$ & $\begin{array}{c}6.538 * * * \\
(2.165)\end{array}$ & $\begin{array}{c}4.845^{* *} \\
(2.185)\end{array}$ \\
\hline Innovation & $\begin{array}{r}-1.935 \\
(1.937)\end{array}$ & $\begin{array}{c}-4.708 * * * \\
(1.692)\end{array}$ & $\begin{array}{l}-1.696 \\
(2.622)\end{array}$ & $\begin{array}{c}-6.400 * * * \\
(2.118)\end{array}$ \\
\hline EU membership & $\begin{array}{c}0.379 \\
(1.109)\end{array}$ & & $\begin{array}{l}-1.148 \\
(1.497)\end{array}$ & \\
\hline Global/debt crisis & $\begin{array}{c}-1.923^{* *} \\
(0.862)\end{array}$ & $\begin{array}{c}-2.962^{* * *} \\
(0.800)\end{array}$ & $\begin{array}{l}-0.840 \\
(1.092) \\
\end{array}$ & $\begin{array}{c}-0.216 \\
(1.031) \\
\end{array}$ \\
\hline Log likelihood function & -592.86 & -606.27 & -98.10 & -109.54 \\
\hline Nr. Of observations & 418 & 418 & 114 & 114 \\
\hline
\end{tabular}

Note: All independent variables are measured at their initial levels at the beginning of each growth period. All specifications include country-fixed effects. Standard errors are in parenthesis. ${ }^{* * *} \mathrm{p}<.01 ;{ }^{* *} \mathrm{p}<.05 ;{ }^{*} \mathrm{p}<.10$

more rapidly than the EU benchmark. However, this effect seems to be limited to the short run because the coefficient lacks significance once growth is extended to 3-year periods.

In contrast, our results show that gross fixed capital formation had an adverse effect on convergence. As with human capital, physical capital accumulation is usually exerts a positive 
influence on growth (Prochniak, 2011). Therefore, our estimates mean that the investments made in CEE countries were not capable of producing growth that exceeded the one in the EU. This finding may indicate that investment spending in CEE was either insufficient or inefficient or both. The lack of fixed capital formation has been particularly evident in the first decade of transition (see Table 1) as state-owned enterprises that had dominated the economy were closed down, restructured, or privatized. In addition, rampant corruption, wasteful use of resources, rigged government tenders for public projects, poor quality, and misguided investment priorities have certainly diminished the effectiveness of invested funds in promoting growth.

Our results further identify economic reforms and liberalization measures as the other key contributor to convergence. Previous studies provide mixed evidence on the growth effects of privatization, price and trade liberalization, and demonopolization. Lawson and Wang (2004) reported a negative effect on growth and convergence speed for all components of the EBRD transition indicator except trade liberalization over the period 1991-2000. In contrast, Fidrmuc (2003), Falcetti, Lysenko, and Sanfey (2006), and Prochniak (2011) discovered a positive growth effect over the same period, while Radulescu and Barlow (2002) failed to find any robust link. We use a significantly longer sample period and focus on growth relative to the EU average. In this framework, progress in the transition from a planned to a market economy has delivered an economic performance that has allowed CEE to catch up with the EU average. Moreover, this effect appears to be sustainable as it extends to 3-year periods of growth as well.

Financial deepening is shown to promote divergence, both in the short and in medium terms. Between 2003 and 2008, most CEE countries experienced an unprecedented credit boom with double digit increases in private lending as a share of GDP. Growth was fueled by large inflows resulting from the high liquidity on global markets that was channeled into CEE via foreign- 
owned banks that dominate the financial sector in many countries in the region (Aydin, 2008; Kongsamut and Vandenbussche, 2013). Accordingly, we would have expected the sign for the coefficient of financial deepening to be positive. However, the credit boom turned to a bust as soon as the global crisis hit the region in 2008-2009. Countries, such as Ukraine, Slovenia, and the Baltics, which had seen private credit growth of over $40 \%$ in the years $2003-2008$, were also the ones that experienced a drop or a slowdown in the convergence of their per-capita GDP relative to the EU average. The dummy for the global and debt crises also indicates that during this period CEE countries diverged on average from the EU benchmark. The cyclical nature of the crises is evident from the lack of significance for the coefficient in the 3-year periods specification. This is in line with our finding in the nonparametric part of the analysis that showed convergence to be generally unaffected by the crises.

Once growth is extended over 3-year periods, the effects of fixed capital formation, financial deepening, and economic reforms remain robust, whereas human capital and the crisis dummy become insignificant. Price instability is the only variable that turns significant over the medium term. In particular, increases in price instability cause relative per-capita income in CEE to diverge from the EU average. Inflation is more generally a sign of macroeconomic instability, especially in CEE where hyperinflation has resulted from price liberalization as well as from banking and financial crises. It is, therefore, not unexpected that this instability retards the narrowing of disparities between CEE and the EU.

Surprisingly, EU membership does not appear to have led to convergence, despite the substantial amounts of financial funds from the EU budget destined for CEE. The specific goal for most of these funds is to decrease the income gap across EU countries by fostering regional economic development and convergence. For instance, the Cohesion Fund provides financial 
support in the areas of trans-European transportation and environment to those EU members with per-capita income of less than $90 \%$ of the EU average, making CEE countries the main beneficiaries. Our findings most likely results from the fact that only a quarter of the sample are EU members, which acceded relatively late in the sample period resulting in few observations. Furthermore, only a few years after these countries joined the organization, the global and debt crises inflicted a setback on their convergence ambitions, especially in the Baltics.

The results of the regression by subperiod, reported in Table 4, reveal several differences between the first and second decades. Human capital exhibits a positive and robust effect only in the years 1990-2001. Similarly, the adverse effect of financial deepening is significant only for the second decade of the sample period, which supports our interpretation above that it is associated with the credit boom and bust in the 2000s. Openness, which was not significant over the entire sample period, is found to exert a positive influence on convergence in the second decade. Moreover, fixed exchange rates appear to have helped CEE countries improve their relative per-capita income standing only in the first subperiod.

\section{Conclusions}

Integration with the EU has been one of the major goals of economic transition in CEE over the past two decades. A number of countries in the region have succeeded in joining the EU, while others are hoping to become members in the near future. However, despite the deepening integration, CEE countries still rank at the bottom in per-capita income terms. This paper examines convergence patterns and tendencies between CEE and the EU average per-capita GDP over the period 1990-2012. In contrast to previous works, we use a combination of parametric and nonparametric methods, which enables us to study the dynamics of the entire income 
Table 4: Regression results for relative annual per-capita GDP growth by subperiod

\begin{tabular}{l|ccc|ccc}
\hline & \multicolumn{3}{|c|}{$1990-2001$} & \multicolumn{3}{c}{$2002-2012$} \\
\hline \multirow{2}{*}{ Fixed capital formation } & $(1)$ & $(2)$ & $(3)$ & $(1)$ & $(2)$ & $(3)$ \\
& $-0.743^{* * *}$ & $-0.828^{* * *}$ & $-0.636^{* *}$ & $-0.164^{* *}$ & -0.152 & $-0.250^{* * *}$ \\
Human capital & $(0.167)$ & $(0.168)$ & $(0.261)$ & $(0.078)$ & $(0.092)$ & $(0.090)$ \\
& $6.646^{* * *}$ & $5.812^{* *}$ & $9.756^{*}$ & 0.233 & 2.663 & $5.323^{* *}$ \\
Openness & $(1.837)$ & $(2.450)$ & $(5.235)$ & $(1.310)$ & $(2.012)$ & $(2.391)$ \\
& -0.031 & -0.040 & 0.002 & $0.085^{* * *}$ & $0.074 * *$ & $0.073^{* *}$ \\
FDI & $(0.031)$ & $(0.030)$ & $(0.059)$ & $(0.029)$ & $(0.033)$ & $(0.033)$ \\
& -0.110 & -0.274 & & 0.016 & 0.016 & 0.007 \\
Fiscal policy & $(0.235)$ & $(0.254)$ & & $(0.046)$ & $(0.050)$ & $(0.050)$ \\
Price instability & -0.038 & & & $0.339 * *$ & 0.258 & 0.081 \\
Financial deepening & $(0.296)$ & & & $(0.146)$ & $(0.166)$ & $(0.176)$ \\
Fixed exchange rate & $-0.004^{* * *}$ & $-0.003^{* * *}$ & -0.001 & $-0.114 * * *$ & $-0.161^{* * *}$ & $-0.124 * * *$ \\
& $(0.001)$ & $(0.001)$ & $(0.004)$ & $(0.031)$ & $(0.039)$ & $(0.042)$ \\
Economic reforms & -0.004 & $0.117^{*}$ & -0.006 & & & $-0.109^{* * *}$ \\
& $(0.046)$ & $(0.069)$ & $(0.065)$ & & & $(0.035)$ \\
Innovation & & $8.721^{*}$ & & -0.025 & -0.145 & 0.394 \\
& & $(4.592)$ & & $(1.779)$ & $(1.791)$ & $(1.926)$ \\
EU membership & & 2.921 & & & $-7.444^{*}$ & -3.156 \\
& & $(2.254)$ & & & $(3.799)$ & $(4.177)$ \\
Global/debt crisis & & & 1.133 & & -2.441 & 0.274 \\
& & & $(5.579)$ & & $(2.239)$ & $(2.506)$ \\
Log likelihood function & -352.07 & -330.25 & -174.86 & -482.47 & -414.41 & -406.59 \\
Nr. Of observations & 209 & 209 & 209 & 209 & 209 & 209 \\
\hline
\end{tabular}

Note: All independent variables are measured at their initial levels at the beginning of each growth period. All specifications include country-fixed effects. Standard errors are in parenthesis. ${ }^{* * *} \mathrm{p}<.01 ;{ }^{* *} \mathrm{p}<.05$; * $\mathrm{p}<.10$

distribution in CEE relative to the EU benchmark and to identify the factors that contribute to or impair convergence.

The results of the distributional and intradistributional analyses indicate that the early years of transition have been marked by income divergence from the EU average, which was only gradually reversed in the late 1990s. During this period, the likelihood of diverging for CEE countries with relative per-capita GDP of less than $40 \%$ was between one and a half and five 
times higher than of catching up with the benchmark. This pattern would have resulted in a highly polarized distribution over the long run with more than half of the sample concentrated in the bottom tercile. Over the years 2000-2012, CEE countries experienced strong income convergence that would have seen almost 70\% of the sample achieve per-capita GDP of more than half the EU average over the long run. At the same time, the relative income distribution over this period evolved from a unimodal to a multimodal one, revealing a growing disparity among the countries in the sample. Although the global and European debt crises appear to have had little impact on the overall convergence tendency, they exacerbated relative income heterogeneity across the region.

The regression analysis shows that progress in economic reforms and human capital were the key determinants of convergence over the entire sample period while trade openness had a positive and significant effect only in the second decade. In contrast, relative income divergence was mainly driven by physical capital accumulation and price instability. Financial deepening had also a significantly adverse impact on convergence, but only in later years when the credit boom of the early to mid-2000s turned into bust at the start of the global crisis. 


\section{References}

AYALA, A., BLAZSEK, S. (2012) How has the financial crisis affected the fiscal convergence of Central and Eastern Europe to the Eurozone?, Applied Economics Letters, 19(5), 471-476.

BABETSKII, I., BOONE, L., MAUREL, M. (2004) Exchange rate regimes and shocks asymmetry: The case of the accession countries, Journal of Comparative Economics, 32, 212-229.

BARRO, R., LEE, J. (2013) A new data set of educational attainment in the world, 1950-2010, Journal of Development Economics, 104, 184-198.

AYDIN, B. (2008) Banking Structure and credit growth in Central and Eastern European countries, IMF Working Paper 08/215.

BECKER, B., HALL, S. (2009) How far from the Euro Area? Measuring convergence of inflation rates in Eastern Europe, Economic Modelling, 26, 788-798.

BRADA, J., KUTAN, A. (2001) The convergence of monetary policy between candidate countries and the European Union, Economic Systems, 25(3), 215-231.

BRADA, J., KUTAN, A., ZHOU, S. (2005) Real and monetary convergence between the European Union's core and recent member countries: A rolling cointegration approach, Journal of Banking \& Finance, 29, 249-270.

DRINE, I., RAULT, C. (2006) Testing for inflation convergence between the Eurozone and its CEE partners, Applied Economic Letters, 13, 235-240.

FALCETTI, E., LYSENKO, T., SANFEY, P. (2006) Reforms and growth in transition: Reexamining the evidence, Journal of Comparative Economics, 34(3), 421-445.

FIDRMUC, J. (2003) Economic reform, democracy and growth during post-communist transition, European Journal of Political Economy, 19(3), 583-604.

FIDRMUC, J., KORHONEN, I. (2003) Similarity of supply and demand shocks between the euro area and the CEECs, Economic Systems, 27(3), 313-334.

FIGUET, J., NENOVSKY, N. (2006) Convergence and shocks in the road to EU: Empirical investigations for Bulgaria and Romania, William Davidson Institute Working Paper 810.

HENDERSON, D., RUSSELL, R. (2005) Human capital and convergence: A production-frontier approach, International Economic Review, 46(4), 1167-1205.

HYNDMAN, R., BASHTANNYK, D., GRUNWALD, G. (1996) Estimating and visualizing conditional densities, Journal of Computational and Graphical Statistics, 5, 315-336. 
KASMAN, A., KIRBAS-KASMAN, S., TURGUTLU, E. (2005) Nominal and real convergence between the CEE countries and the EU: A fractional cointegration analysis, Applied Economics, 37(21), 2487-2500.

KOCENDA, E. (2001) Macroeconomic convergence in transition countries, Journal of Comparative Economics, 29(1), 1-23.

KOCENDA, E, KUTAN, A., YIGIT, T. (2008) Fiscal Convergence in the European Union, North-American Journal of Economics and Finance, 19(3), 319-330.

KUTAN, A., YIGIT, T. (2004) Nominal and real stochastic convergence of transition economies, Journal of Comparative Economics, 32, 23-36.

KUTAN, A., YIGIT, T. (2005) Real and nominal stochastic convergence: Are the new EU members ready to join the Euro zone?, Journal of Comparative Economics, 33(2), 387-400.

KONGSAMUT, P., VANDENBUSSCHE, J. (2012) The Eastern European experience with macroprudential policies: Evidence from Bulgaria, Croatia, Romania and Serbia during the latest credit boom-bust cycle, IMF Working Paper, forthcoming.

LAWSON, C., WANG, H. (2004) Economic transition in central and eastern Europe and the former Soviet Union: which policies worked?, University of Bath Department of Economics and International Development Working Paper.

LEVINE, R., RENELT, D. (1992) A sensitivity analysis of cross-country growth regressions, American Economic Review, 82, 942-63.

MATKOWSKI, Z., PROCHNIAK, M. (2007) Economic convergence between the CEE-8 and the European Union. Eastern European Economics, 45(1), 59-76.

NATH, H., TOCHKOV, K. (2013) Relative inflation dynamics in the new EU member countries of Central and Eastern Europe, Empirical Economics, 45(1), 1-22.

RADULESCU, R., BARLOW, D. (2002) The relationship between policies and growth in transition countries, Economics of Transition, 10(3), 719-745.

RAPACKI, R., PROCHNIAK, M. (2009) Real beta and sigma convergence in 27 transition countries, 1990-2005, Post-Communist Economies, 21(3), 307-326.

PROCHNIAK, M. (2011) Determinants of economic growth in Central and Eastern Europe: The global crisis perspective, Post-Communist Economies, 23(4), 449-468.

QUAH, D. (1993) Empirical cross-section dynamics in economic growth, European Economics Review, 37, 426-434.

QUAH, D. (1996a) Empirics for economic growth and convergence, European Economic 
Review, 40, 1353-1375.

QUAH, D. (1996b) Twin Peaks: growth and convergence in models of distribution dynamics', Economic Journal vol. 106, 1045-1055.

QUAH, D. (1997) Empirics for growth and distribution: stratification, polarization and convergence clubs, Journal of Economic Growth vol. 2, 27-59.

SALA-I-MARTIN, X., DOPPELHOFER, G., MILLER, R. (2004) Determinants of long-term growth: A Bayesian averaging of classical estimates (BACE) approach, American Economic Review, vol. 94(4), 813-35.

SZELES, M., MARINESCU, N. (2010) Real convergence in the CEECs, euro area accession and the role of Romania, European Journal of Comparative Economics, vol. 7(1), 181-202.

TSANANA, E., KATRAKILIDIS, C. (2013) Do Balkan economies catch up with EU? New evidence from panel unit root analysis, Empirica, forthcoming.

TSANANA, E., KATRAKILIDIS, C., PANTELIDIS, P. (2013) Balkan Area \& EU-15: An empirical investigation of Income Convergence, in Karasavvoglou, A., Polychronidou, P. (eds.) Balkan and Eastern European Countries in the Midst of the Global Economic Crisis, Springer, 23-33.

VOJINOVIC, B., OPLOTNIK, Z., PROCHNIAK, M. (2010) EU enlargement and real economic convergence, Post-Communist Economies, vol. 22(3), 303-322. 


\section{DAVIDSON INSTITUTE WORKING PAPER SERIES - Most Recent Papers}

The entire Working Paper Series may be downloaded free of charge at: www.wdi.umich.edu

CURRENT AS OF $11 / 26 / 13$

\begin{tabular}{|c|c|c|}
\hline Publication & Authors & Date \\
\hline $\begin{array}{l}\text { No. 1063: The Distribution Dynamics of Income in Central and Eastern } \\
\text { Europe relative to the EU: A Nonparametric Analysis }\end{array}$ & $\begin{array}{l}\text { Nickolay Nenovsky \& } \\
\text { Kiril Tochkov }\end{array}$ & Nov 2013 \\
\hline $\begin{array}{l}\text { No. 1062: Reactions to shocks and monetary policy regimes: inflation } \\
\text { targeting versus flexible currency board in Ghana, South Africa and the } \\
\text { WAEMU }\end{array}$ & $\begin{array}{l}\text { Fadia Al Hajj' Gilles Dufrénot, } \\
\text { Kimiko Sugimoto, Romain Wolf }\end{array}$ & Nov 2013 \\
\hline No. 1061: Distribution Dynamics of Russian Regional Prices & Konstantin Gluschenko & Oct 2013 \\
\hline $\begin{array}{l}\text { No. 1060: Institutional Polycentrism, Entrepreneurs' Social Networks, And } \\
\text { New Venture Growth }\end{array}$ & $\begin{array}{l}\text { Bat Batjargal, Michael Hitt, Anne } \\
\text { Tsui, Jean-Luc Arregle, Justin } \\
\text { Webb and Toyah Miller }\end{array}$ & Sept. 2013 \\
\hline No. 1059: Price Jumps on European Stock Markets & $\begin{array}{l}\text { Jan Hanousek, Evžen Kočenda, } \\
\text { and Jan Novotný }\end{array}$ & Sept. 2013 \\
\hline $\begin{array}{l}\text { No. 1058: Lessons Learned from Tax vs. Expenditure Based Fiscal } \\
\text { Consolidation in the European Transition Economies }\end{array}$ & Rajmund Mirdala & Sept. 2013 \\
\hline $\begin{array}{l}\text { No. 1057: Structural Reforms and Growth in Transition: } \\
\text { A Meta-Analysis }\end{array}$ & Jan Babecky and Tomas Havranek & Aug 2013 \\
\hline No. 1056: Cross-Country Heterogeneity in Intertemporal Substitution & $\begin{array}{l}\text { Tomas Havranek, Roman } \\
\text { Horvath, Zuzana Irsova } \\
\text { \& Marek Rusnak }\end{array}$ & Aug 2013 \\
\hline $\begin{array}{l}\text { No. 1055: Is women's ownership of land a panacea in developing } \\
\text { countries? Evidence from land-owning farm households in Malawi }\end{array}$ & $\begin{array}{l}\text { Sumon K. Bhaumik, Ralitza } \\
\text { Dimova \& Ira N. Gang }\end{array}$ & Aug 2013 \\
\hline No. 1054: Specialization, gravity, and European trade in final goods & $\begin{array}{l}\text { Richard Frensch, Jan Hanousek } \\
\text { and Evzen Kocenda }\end{array}$ & July 2013 \\
\hline $\begin{array}{l}\text { No. 1053: Public Debt Sustainability in Africa: Building Resilience and } \\
\text { Challenges Ahead }\end{array}$ & $\begin{array}{l}\text { Zuzana Brixiova and } \\
\text { Mthuli Ncube }\end{array}$ & July 2013 \\
\hline $\begin{array}{l}\text { No. 1052: YOUTH EMPLOYMENT IN AFRICA: NEW EVIDENCE AND POLICIES } \\
\text { FROM SWAZILAND }\end{array}$ & $\begin{array}{l}\text { Zuzana Brixiova and Thierry } \\
\text { Kangoye }\end{array}$ & June 2013 \\
\hline No. 1051: Oil Windfalls, Fiscal Policy and Money Market Disequilibrium & $\begin{array}{l}\text { Salman Huseynov, Vugar } \\
\text { Ahmadov }\end{array}$ & June 2013 \\
\hline No. 1050: Price Jump Indicators: Stock Market Empirics During the Crisis & $\begin{array}{l}\text { Jan Novotný, Jan Hanousek, and } \\
\text { Evžen Kočenda }\end{array}$ & June 2013 \\
\hline $\begin{array}{l}\text { No. 1049: Impact of Financial Deregulation on Monetary \& Economic } \\
\text { Policy in the Czech Republic, Hungary and Poland: } 1990-2003\end{array}$ & Patricia McGrath & May 2013 \\
\hline $\begin{array}{l}\text { No. 1048: The 90\% Public Debt Threshold: The Rise \& Fall of a Stylised } \\
\text { Fact. }\end{array}$ & Balázs Égert & May 2013 \\
\hline $\begin{array}{l}\text { No. 1047: The efficiency and equity of the tax and transfer system in } \\
\text { France }\end{array}$ & Balázs Égert & April 2013 \\
\hline No. 1046: Optimal Resource Rent & Rustam Jamilov & Mar 2013 \\
\hline $\begin{array}{l}\text { No. 1045: Financial Development and Economic Growth: } \\
\text { A Meta-Analysis }\end{array}$ & $\begin{array}{l}\text { Petra Valickova, Tomas Havranek } \\
\text { and Roman Horvath }\end{array}$ & Mar 2013 \\
\hline No. 1044: Incomplete Specialization \& Trade in Parts \& Components & $\begin{array}{l}\text { Richard Frensch, Jan Hanousek \& } \\
\text { Evzen Kocenda }\end{array}$ & Mar 2013 \\
\hline
\end{tabular}

